sistency of executive councils in their criteria for approving and controlling deputizing services. Most executive councils apply controls on the quantity of usage and seem to believe that a control of quantity is a conirol of quality. The association of which I am secretary firmly believes that this policy is wrong. A service has to provide a high quality at all times and any service which is good on only "two nights a week" has no right to be in existence at all.

It is true that larger group practices appear to use deputizing services to a lesser extent, but the reasons for this might be more complex than those suggested. The method by which a deputizing service charges the general practitioner varies from area to area and has also varied over the years. In some cases the charging structure has been a deterrent to group practices and this has been particularly so where the service has insisted that every member of a group becomes a user and has provided no facility for individuals to join without their colleagues. In those areas where this deterrent has not operated, our figures would suggest that the percentage of group practice users is very much higher.

We have always believed that the best judge of a deputizing service is the practitioner who uses it. By this measure we firmly believe that deputizing services are of the standard the public has the right to expect. The article suggests that the acceptability of deputizing services by the public is an unknown quantity. Deputizing services in the past 12 months visited 750,000 patients. If one compares this with the number of grumbles, both public and private, then we would suggest that it is self-evident that the public is also satisfied.-I am, etc.,

Michael OGNALl Medical Directors Association

Scarcroft, near Leeds

\section{Amitriptyline and Imipramine Poisoning in Children}

SIR,-One great hazard associated with the publication of scientific papers and the delivery of lectures in public is-as I know from my own sad experience years agothat the national press may publish extracts, possibly with banner headlines, which can grossly mislead the lay public.

The Daily Mirror on 15 February last published an article headed "Peril of the 'Killer Drugs' for Children" based on the paper by Drs. K. M. Goel and R. A. Shanks in the B.M.f. (16 February, p. 261). The consequence was that one mother came to me with her daughter, who had been taking imipramine for enuresis, and said she was discontinuing this because of the risk of heart trouble. Furthermore, the mother attributed the daughter's episode of vague malaise with left-sided chest pain before Christmas 1973 to the same cause. Later in the surgery a middle-aged male diabetic who had had a myocardial infarction told me he would take no more amitriptyline for his depression because the newspaper article said it damaged the heart.

The paper by Drs. Goel and Shanks does not make clear, to the lay reader, whether poisoning was due to therapeutic doses or aocidental overdose. Consequently the Daily Mirror article conveys the impression that therapeutic dosage was to blame. May I
appeal to all authors of medical papers try to avoid any possibility of misunderstanding by those journalists who have the task of scrutinizing medical journals for items which are sensational and therefore wanted by the national press?-I am, etc.

Stapleford, Nottingham

RALPH N. WILSON

\section{I.Q. of Parents of Battered Babies}

SIR,-It seems that Dr. Clare A. Hyman (22 December, p. 739) may not have observed that in our paper "Parents of Battered Babies: A Controlled Study" (17 November, p. 388) we described not one but many abnormal parental attributes. Singling out "stupidity" to explain baby battering may indeed prolong the myth erroneously attributed to us.

Though our method of using a short form of the Wechsler Adult Intelligence Scale (W.A.I.S.) is criticized, Dr. Hyman fails to mention what subtests she herself used. Furthermore, the assumption that one particular choice of subjects is permissible is erroneous in that it has been shown that all possible combinations of four subtests of the W.A.I.S. (including ours) correlate $(r=0.90$ or higher) with full-scale testing. I Indeed, the inability of battering parents to foresee the consequences of their actions is probably best reflected by the content of the subtests we chose-namely, comprehension, vocabulary, block design, and picture arrangement, which are also very good subtests of verbal and non-verbal ability.

With regard to the use of "averaged scores," a term not found in our paper, it may be pointed out that several wellrecognized methods of arriving at an estimate of a full scale I.Q. have been used. ${ }^{2}$ One of these was the method used in our study. It is wrong to assume that had we adopted either an alternative short form of the W.A.I.S. or an alternative method of estimating the average I.Q. for the group, the 15-point difference between the index and control groups might have disappeared. ${ }^{34}$

Dr. Hyman has, however, correctly observed that "little research ... has been carried out into the intellectual functioning of battering parents." In fact no quantified data concerning this, other than our own, have been previously published. It is a mistake, therefore, to insist that the low verbal abilities of battering parents can be attributed to "withdrawal, depression, and non-communicativeness"; an assumption of this type could be justified only by giving a full W.A.I.S. (Maxwell, A. E., personal communication, 1974). Neither do the clinical features Dr. Hyman observed constitute in themselves "a consistent personality pattern" on Cattell's 16 PF test. Cattell himself made no such claim. Furthermore, Dr. Hyman's results are also at variance with Wechsler's prediction ${ }^{6}$ and Brown's findings ${ }^{7}$ that verbal abilities are the ones least affected by psychiatric disturbance.

It would have been useful if Dr. Hyman had defined her sample. The strength of our results rests on choosing a sample of parents of acutely hospitalized battered babies. It could be assumed that Dr. Hyman's sample includes many parents voluntarily seeking the help of the N.S.P.C.C. It could also be assumed that these might constitute a more intelligent group.

The broad design of our study, a section of which has recently been published (17 November, p. 388), is intended to put into perspective the various narrow theories that have for too long absorbed great expenditure of effort.-We are, etc.,

RUTH HANSON SELWYN SMITH

University Department of Psychiatry,

Queen Elizabeth Hospital,

Maxwell, A. E., fournal of Consulting Psychology, $1957,21,121$,

2 Levy, P., Psychological Bulletin, 1968, 69, 410 Watson, C. G., Fournal of Consulting Psychology,

, B., Psychological Reports, 1967, 20,

Cattell, R. B., Eber, H. W. C., and Tatsuoka, 1. N., Handbook for the 16 Personality Factor Questionnaire. Champaigne, Illinois, In

Wechsler, D. The Measurement and Appraisal of Adult Intelligence, 4th edn. London, Bailliere, Tindall and Cox, 1958

7 Brown, O., Psychological Reports, 1967, 20, 1015.

\section{Anticoagulants and Treatment for Chilblains}

SIR,-We wish to bring to notice the serious adverse effects on anticoagulant therapy of a proprietary preparation which is generally available to the public and advertised as being for the relief and prevention of chilblains.

A patient with mitral stenosis and atrial fibrillation was started on prophylaxis with nicoumalone as an outpatient in August 1972. She was adequately anticoagulated until her last visit to the anticoagulant clinic in January 1974, when her British corrected ratio was only 1.2 (conventional therapeutic range 1.8-3.0). She reported that she had been taking a proprietary preparation named Gon for 48 hours previously, taking three tablets on the first day and two on the day of her visit to the clinic. This preparation contains, in addition to $50 \mathrm{mg}$ of nicotinamide, $10 \mathrm{mg}$ of vitamin $\mathrm{K}$ (acetomenaphthone) per tablet. The manufacturer's recommended dose for treating chilblains is six tablets daily.

There is no warning on the container regarding any adverse effects and no reference to the neutralizing effect of vitamin $K$ on oral anticoagulant administration.-We are, etc.,

G. E. HEALD L. POLLER

Department of Haematology,

Withington Hospital,

Manchester

Remission of Diabetes during Pregnancy

SIR,-The paper by Drs. Joanne Sheldon and Timothy Coleman (12 January, p. 55) illustrates very well the limitations of trying to judge disorders of carbohydrate metabolism in terms only of the concentration of glucose in the blood. It seems somewhat illogical to class a woman whose diabetes is sufficient to cause the death of her baby, with all the classical stigmata, as being in "remission".

How can deterionation or improvement be judged? Visual inspection of the curves given for case 1 shows that they are of remarkably similar shape. Because only four samples were taken per test it is not possible to calculate an " $H$ " value," but it seems doubtful that any reduotion in this 